\title{
Sobre o método psicanalítico em tempos de COVID-19 e atendimentos remotos
}

\author{
Regarding the psychoanalytical method in COVID-19 \\ times and remote assessment
}

\section{Ísis Gonzalez Fossati}

Resumo: Em março de 2020, o vírus da COVID-19 chegou ao país e, junto dele, a necessidade de repensarmos as formas de se manter em contato com o outro, inclusive, em processos de tratamento analítico. Desde a sua chegada, o vírus impôs inúmeras alterações na rotina das pessoas, e, a isso não se escapa o momento reservado aos atendimentos clínicos, que, na impossibilidade de se manterem presenciais, precisaram migrar para meios outros que pudessem, de alguma forma, sustentar o vínculo e a relação existente até então. Entendendo que em momentos de excesso e, principalmente, de muitas dúvidas, precisamos recorrer a bases que sejam sólidas, para que, enquanto analistas, possamos nos manter continentes, o presente escrito propõe uma revisão narrativa da literatura que objetiva revisitar as origens e os fundamentos que norteiam o método psicanalítico, visto que tais preceitos são alicerces constitutivos para o ofício da psicanálise. Ainda, o presente trabalho abordará possíveis dificuldades enfrentadas quanto a aplicabilidade do método, nesse período de grandes incertezas.

Palavras-chave: Psicanálise; Método; Atendimento Remoto.
Abstract: In March 2020, the COVID-19 virus reached the country and, with it, the necessity of reassessing the ways to maintain contact with others, including, in the process of analytical treatment. Since its arrival, the virus has imposed innumerous adjustments in people's routines, and, from this it is not exempt the moment reserved for clinical care, that, with the impossibility of remaining presential, required to migrate to other means that could, somehow, sustain the bond and relation existing until then. Understanding that in moments of excess, and mainly, of many doubts, we need to resort to foundations that are solid, with which, as analysts, we can remain conscientious, this document proposes a narrative review of the literature that aims to revisit the origins and the fundamentals that guide the psychoanalytical method, since such precepts are the constitutive cornerstones for the craft of psychoanalysis. Nevertheless, this work will address possible difficulties encountered concerning the applicability of the method, in this time of great uncertainties.

Keywords: Psychoanalysis; Method; Remote Assessment.

\footnotetext{
1 Psicóloga pela Pontifícia Universidade Católica do Rio Grande do Sul, psicanalista em formação e membro associado da Sigmund Freud Associação Psicanalítica. E-mail: isis.fossati@gmail.com
} 


\section{Introdução}

Sigmund Freud em um de seus textos mais belos, "A transitoriedade" (1916/2010), ao discorrer sobre o período de guerra, aponta: "(...) despojou-nos de muitas coisas que amávamos, e revelou a fragilidade de tantas outras que acreditávamos sólidas" (p.251). Salvo as devidas comparações entre o momento histórico de guerra e o panorama atual, de pandemia mundial, muitos têm considerado o vigente período como igualmente traumático. Desde a chegada do vírus da COVID-19 ao Brasil, todas as esferas da sociedade precisaram repensar e, criativamente, encontrar formas para que as relações não se perdessem, e, dessa forma, fez-se necessário repensar as formas de se manter em contato com o outro. Ante a tal dificuldade e, para muitos, a impossibilidade, inclusive os processos de tratamento analítico precisaram ser repensados e reinventados, migrando para meios que pudessem, de alguma forma, sustentar o vínculo e a relação existente até 0 momento. Considerando que os fundamentos que alicerçam 0 ofício psicanalítico não se apresentam como frágeis e que podemos recorrer a eles, principalmente, em momentos como 0 atual, de grandes incertezas e excessos, o presente artigo propõe revisitar as origens e os fundamentos que norteiam o método psicanalítico, para, por fim, abordar possíveis dificuldades enfrentadas quanto a aplicabilidade do método.

\section{Método}

0 presente artigo trata-se de uma revisão bibliográfica sobre a temática do método psicanalítico frente às possibilidades de atendimentos remotos, de acordo com Gil (2008), trata-se de uma pesquisa"desenvolvida a partir de material já elaborado, constituído de livros e artigos científicos" (p. 50). Para a escrita deste trabalho, foram utilizados textos clássicos da obra freudiana, além de livros que abordassem a temática proposta, em língua portuguesa. Além disso, foram consultados artigos científicos, publicados em periódicos indexados nas bases de dados Scielo, Lilacs e Pepsic, com as palavras chave: "método psicanalítico", "atendimento remoto" e "atendimento psicanalííco on-line". Também foram consultados sites de revistas psicanalíticas, em língua espanhola, e blogs de psicanalistas que contribuíssem para fundamentar e desenvolver a escrita sobre 0 tema.

\section{Arqueologia do método}

É fundamental lançar luz e retomar a definição de psicanálise feita por Freud, em 1922, de acordo com Hornstein (1989):

1. um procedimento que serve para investigar processos anímicos dificilmente acessíveis por outras vias; 2. um método de tratamento das perturbações neuróticas, fundado nessa investigação; 3. uma série de concepções psicológicas, obtidas por esse caminho, que pouco a pouco foram se constituindo em uma nova disciplina cientíica (p. 19).

Dito isso, o presente escrito irá discorrer sobre o segundo ponto, o método psicanalítico, e, para tanto, seráfeita uma retomada a alguns textos anteriores a postulação de 1922, e que são considerados seminais, como, por exemplo "A psicoterapia da histeria" (1895/2016), onde Freud (2016) ainda se utilizava do método catártico, que consistia em buscar obter a cura através da "liberação do afeto desviado, e a sua descarga por vias normais (ab-reação)" "Laplanche \& Pontalis, 1992, p. 61).

Logo no início texto, "A psicoterapia da histeria" (1895/2016), Freud (2016) pondera sobre dois dos motivos que teriam Ihe afastado do método breueriano, "da cura de sintomas histéricos por investigação e ab-reação na hipnose" (p. 360), dentre esses motivos há um, em especial, que nos interessa e pode ser considerado um passo importante para a origem do método psicanalítico, diz o autor: "nem todas as pessoas que mostravam sintomas histéricos indiscutíveis e nas quais, muito provavelmente, prevalecia o mesmo mecanismo psíquico, eram hipnotizáveis" (p. 360). Além disso, de acordo com 0 autor, em muitas ocasiões, quando se propunha a trabalhar com o método catártico em casos em que, aparentemente, se confirmava o diagnóstico de histeria, defrontava-se com "resultados terapêutico muito pobres, [em que] mesmo a análise não traziaà luz nada de significativo" (p. 361), mais adiante, no texto anteriormente referido, Freud (2016) ainda aponta, como obstáculos ao método catártico, a ineficácia frente a casos de neurastenia, e, em grande parte das neuroses de angústia, além de observar que o método: "não pode impedir que novos sintomas surjam no lugar dos eliminados" (p. 368).

Ainda assim, antes de, efetivamente, abandonar o método catártico, 0 autor já demonstrara indícios de que, ainda que de forma bastante incipiente, o pensamento psicanalítico já estava começando a rondá-lo, ganhando espaço e chamando a sua atenção, em sua prática:

(...) ordenava aos doentes que se deitassem e fechassem deliberadamente os olhos para se 'concentrar', o que ao menos resultava em certa semelhança com a hipnose. Tive assim a experiência de que sem qualquer hipnose emergiam novas e mais recuadas lembranças [grifo nosso], que provavelmente diziam respeito a nosso tema. Tais experiências deram-me a impressão de que seriade fato possivel trazer àluz, por mera insistência, as séries deideias patogênicas quesem dúvida havia [grifo nosso] (p. 377).

A "insistência" relatada por Freud (2016), contribuiu para que 0 autor percebesse que, através dessa possibilidade de prática, a ele seria necessário "vencer uma força psíquica que se opunha, no paciente, a que as ideias patogênicas se tornassem conscientes (fossem lembradas)" (p. 377), e, nesse momento, Freud (2016) desenvolve o seu pensamento para a proposição de que, seria papel do terapeuta"vencer essa resistência à associação por meio de um trabalho psíquico" (p. 379). Éimportante salientar que, nesse momento da obra, 0 autor se deparou com as resistências encontradas em seus pacientes. No entanto, apesar de não ser escopo do presente trabalho, considero relevante citar a passagem como forma de chamar a atenção para, como já dito, uma perspectiva embrionária do que viria, também, a compor a psicanálise.

Data, ainda, de 1889, outro momento considerado chave para a história da psicanálise; ao dar início ao tratamento de Emmy Von N., senhora que, de acordo com Freud (1997), possuía "sintomas [que] me interessaram de tal forma que the dediquei grande parte de meu tempo e decidi fazer tudo 0 que estivesse ao meu alcance para recuperá-la" (p. 45) quando Freud é inter- 
rompido, aos gritos repletos de angústia, da paciente: "Fique quieto! - Não diga nada! - Não me toque!" (p. 46) é, a partir desse momento, que o autor, ao atender as exigências de Emmy, passa a considerar a importância devida não apenas para a fala, como, também, da escuta.

Portanto, a partir da consideração dos obstáculos anteriormente citados e de seu interesse por entender os fenômenos que observava em sua clínica, Freud passa, então, a abandonar o método catártico, que, esteve - na maior parte do tempo - mais relacionado à prática hipnótica, e se debruça sobre um método que se alicerça na proposição de uma sugestão às pacientes, bem como, a um artifício técnico, como referem Laplanche e Pontalis (1992): "uma pressão com a mão na testa do paciente" (p. 61). Desse modo, Freud dá início a uma nova fase em seu pensamento e exercício clínico, em uma clara demonstração de constante reflexão e crítica que, sem dúvida, contribuíram para a formulação do método psicanalítico.

\section{Constitui-se o método}

À época em que se lança a esta nova prática, deixando para trás 0 método catártico, Freud (2016) narrou como trabalhava e, o que nos é mais caro, a instrução que dava aos pacientes antes de pressionar as suas testas e, finalmente, perguntar-Ihes o que haviam visualizado ou o que havia Ihes ocorrido. 0 autor informava ao paciente que:

(...) no decorrer dessa pressão verá diante de si uma lembrança, como imagem, ou a terá em pensamentos, como ideia inesperada, e o obrigo a me comunicar essa imagem ou essa ideia, sejam quais forem. Não deve guardá-la para si por achar, talvez, que não seja a buscada, a certa, ou porque Ihe seja desagradável demais expressá-I0. Não deve haver nenhuma crítica, nenhuma reserva, seja por afeto ou por menosprezo! Só assim podemos encontrar o que buscamos, assim o encontraremos infalivelmente (p. 380).

No entanto, apesar de reconhecer que, em muitos momentos, a pressão sobre a testa poderia ser amplamente substituída por qualquer outro estímulo físico, ou mesmo nenhum, Freud (2016) entendia que a pressão na testa, ou, em alguns casos, segurar a cabeça do paciente caracterizaria em algo "mais sugestivo, e cômodo que posso fazer para esse fim" (p. 380). É possível compreender a lógica por trás deste pensamento, visto que, ao deslocar a atenção do paciente para algo do ambiente externo, Freud (2016) contribuía, assim, para a dissociação da atenção "do doente de sua busca e reflexão conscientes, de tudo aquilo que, enfim, em que pode se manifestar sua vontade, de maneira semelhante ao que ocorre quando se ol ha fixamente para uma bola de cristal, etc." (p. 380), ou seja, o próprio autor demonstrava perceber que, tal atitude, nada mais representava que um artifício que, sem dúvida, contribuía para uma espécie de reflexão imersiva por parte do paciente.

Esse momento histórico é, sem dúvida, de grande significado para a constituição da obra freudiana, pois, ao descrever tais achados, Freud (2016) percebe, também, que as ideias que, eventualmente, causavam algum tipo de mal estar ou incapacidade em seus pacientes, estariam sempre próximas de se tornarem acessíveis. No entanto, tais ideias não seriam as primeiras a emergirem durante o processo terapêutico, sendo bastante comum que ideias relacionadas às ideias patogênicas dessem início a um encadeamento de ideias, constituindo "um ponto de partida de uma nova série de pensamentos e lembranças, ao final da qual se encontra a ideia patogênica" (p. 381). Freud (2016) percebeu, ainda, que, ao se aproximarem do caminho que levaria a tal ideia, no entanto, os pacientes tendiam a interromper seu fluxo de ideias, 0 que tornava necessária a repetição da instrução, bem como da pressão sobre suas testas, mas, de maneira geral, após algum tempo trabalhando dessa maneira, os pacientes apresentavam-Ihe facetas mais colaborativas e "uma profusão de reminiscências lhe ocorre [ao paciente] então, sem que seja preciso apresentar-Ihe perguntas e tarefas; (...) fazemos bem em deixá-lo reproduzir esse material, por algum tempo, livre de influências" (p. 410).

Propondo aos seus pacientes, que não deveriam guardar para si pensamentos ou ideias que parecessem desagradáveis ou sem sentido e que, ao fazê-lo, não precisariam ter vergonha ou receio, Freud, de forma aparentemente - despretensiosa, deu vida ao que hoje conhecemos como regra fundamental, que, conforme Laplanche e Pontalis (1992), "estabelece no princípio do tratamento psicanalítico o método das associações livres" (p. 438). A associação livre, portanto, já se mostrava, em alguma medida, presente no método aplicado por Freud, quando ele afirma que seus pacientes, através de suas falas, "fornecem material que, mais tarde, ao ser percebida uma conexão, é reavivado" (Freud, 2016, p. 410).

A associação livre só foi se instaurar, enquanto - efetivamente - uma regra fundamental, em textos posteriores aos revisitados no presente trabalho, no ano de 1909, mas, ainda assim, se manteve fiel ao que Freud propunha anos antes, o paciente deveria "dizer tudo, e apenas dizer; suas emoções, as suas impressões corporais, as suas ideias, as suas recordações" (Laplanche \& Pontalis, 1992, p. 439). A noção de que a associação seja livre parte da conjectura que 0 analista, diante ao paciente, não deve Ihe fornecer qualquer ponto de partida, por onde dar início ao seu discurso e, nesse sentido, torna-se impossível não relembrar a contribuição de Emmy Von N., que, antes mesmo que Freud já pudesse ter delineado com clareza o método psicanalítico, já se demonstrava apropriada do processo ao qual estava proposta a se submeter.

No texto, "O método psicanalítico freudiano"(1904/2019), Freud (2019a) aponta ao leitor que, ao dar passos em rumo a sua própria formulação técnica, teórica e metodológica, passara a realizar 0 atendimento de seus pacientes em uma conformidade que é conhecida até hoje:" que eles se posicionem confortavelmente em um divã, sem qualquer outro tipo de influenciamento (...) não exige que fechem os olhos e evita qualquer contato e todo procedimento que possa lembrar a hipnose" (p. 53). 0 autor segue o texto discorrendo sobre como a sessão, a partir dos pressupostos psicanalíticos, decorreria e traça paralelo com a ideia de que seria como uma conversa entre duas pessoas, sem que uma delas estivesse sob efeito de sugestão ou hipnose, mas, do contrário, tão desperta e atenta quanto a outra pessoa, no caso, 0 analista (p. 53).

Alonso (2011) descreve que, conforme Freud foi, não apenas, introduzindo a noção de inconsciente à sua obra como, também, abrindo caminho e desenvolvendo a sua escuta para "0 sentido dos sonhos, a psicopatologia da vida cotidiana" (p. 108), foi possível que um fato novo se instaurasse e, com ele:

(...) a ampliação do campo do discurso como 0 caminho do analítico. A instauração da situação analítica, propondo a regra fundamental - a livre associação e o seu reverso, a atenção 
flutuante -, produz um desfraldar da palavra. No seio da associação livre vai-se produzindo um descolamento da imagem, do fato como fixo (...) tudo isso vai dando tonalidades diferentes àquelas figuras que não passam despercebidas à escuta sutil da atenção flutuante (p. 108).

A associação-livre, por parte do paciente, encontra o seu correspondente, por parte do analista, na atenção flutuante, introduzida no texto "Recomendações ao médico para o tratamento psicanalítico" (1912/2019). Nesse texto, Freud (2019b) enuncia conselhos sobre como deveria se proceder o tratamento a partir de um pensamento psicanalítico, entre os quais, há alguns pontos que merecem especial atenção para o tema citado anteriormente, como, por exemplo, a indicação de que o médico (analista) não deve realizar anotações de quaisquer espécie no decorrer do atendimento, a não ser em situações que demandem a lembrança de datas ou achados muito específicos. Essa indicação aponta para a existência de uma escuta aguçada, que não recorre, necessária e exclusivamente, à memória, mas, também, ao que suscita maior atenção ao analista a quem se fala. Sobre essa escuta, sustenta como 0 analista deve proceder:

(...) não querer memorizar algo específico e dispensando a mesma 'atenção equiflutuante' ao que ouvimos (...) afiamos a atenção intencionalmente até um determinado ponto, começamos a selecionar em meio ao material apresentado; fixamos um parte de maneira bastante acurada, eliminando outra em seu lugar e, nessa seleção, fiamos as nossas expectativas (p. 94).

Ao seguir em suas considerações, 0 autor indica de forma bastante objetiva e clara: "Éfácil inferir em qual objetivo essas regras aqui apresentadas confluem. Elas todas querem criar no médico o contraponto da'regra psicanalítica fundamental"' (p. 98). Com isso, Freud (2019b) propunha, portanto, que tanto analista quanto paciente tivessem uma indicação, (da parte do analista, conhecida a priori, da parte do paciente, conhecida na relação estabelecida com 0 analista) de por onde o método psicanalítico poderia transitar.

\section{0 método psicanalítico ante à COVID-19}

Apresentado o caminho percorrido e a constituição do método psicanalítico, ingressamos em um aspecto que surge como ponto chave de discussão do presente trabalho: é possível manter o método psicanalítico nos atendimentos remotos que vem sendo realizados desde março de 2020, situados em um momento de inéditos (des)arranjos logísticos, profissionais e até mesmo psíquicos? É possível que nós, enquanto analistas, resistamos ao tentador convite de, em muitos momentos, retornarmos a um método sugestivo, ou mesmo, ao método catártico, como forma de escoar os excessos que podem ser vivenciados em tempos de maior isolamento físico? Mais do que respostas, proponho que possamos conhecer e nos apropriarmos do que foi escrito, até o momento, sobre as possibilidades e, eventuais dificuldades presentes em atendimentos remotos.

Em seu mais recente livro, Belo (2020) nos apresenta a proposição de que a (auto)análise de Freud com seu amigo e confidente, Fliess, como assim é denominada e conhecida a troca de cartas ocorrida entre eles, chama a atenção para o fato de que: "boa parte dessa relação tenha se sustentado pela palavra desencarnada da carta. Nem voz, nem imagem: a palavra escrita como recurso de endereçamento do desejo de ser ouvido, compreendido, acolhido" (p. 17). Ou seja, essa era a possibilidade de troca, de acompanhamento remoto à época, muito diferente das que, hoje, podemos lançar mão, através de voz e, em alguns casos, imagem. E recorrendo ao que 0 autor pontua: "se o próprio nascimento da psicanálise se nutriu da virtualidade, é razoável que possamos abrir espaço para análises à distância" (Belo, 2020, p. 19).

Fink (2017) no texto "Análises por telefone, variações na situação psicanalítica", se posiciona bastante favorável à possibilidade de que existam, sim, análises, por telefone, apesar de frisar que, em alguns casos, ou melhor dizendo, para alguns pacientes, a análise por telefone não seria indicada, 0 autor considera: "0 que parece absolutamente essencial é a escuta: analista e paciente devem ser capazes de ouvir um ao outro. É o que a paciente diz, e como ela diz, que é de grande importância em análise" (p. 323). Considerando estritamente o fator escuta, por parte do analista, é impossivel não retornarmos àquela que é a sua contrapartida, diante à associação livre: a atenção equiflutuante. Em relação a esse aspecto, considerando aqueles atendimentos que sejam realizados por chamada de vídeo, Nóbrega (2015), escreve: "0 analista deverá se acostumar aos poucos a não ter contato visual com o cliente, para manter a atenção flutuante" (p. 146). A partir dessa acepção, poderíamos inferir, portanto, que o estímulo visual prejudicaria a escuta do analista, mas, nesse sentido, como se explicariam os atendimentos em que os pacientes se encontram sentados em poltronas?

Seguindo por este aspecto, Rivera (2020) escreveu, ainda no início da pandemia sobre como entendia a possibilidade de atenção equiflutuante na modalidade de atendimentos remotos:

(...) em vez de recortar trechos do campo visual em enquadramentos precisos (em imagens), como em uma tela, e agenciá-los narrativamente como se montasse um filme, a atenção flutuante implica, assim, a noção de espaço - o espaço aberto para o desfocado, para o impreciso, para os deslocamentos que impedem a nitidez. E é nesse espaço que podem então se ressaltar, em detrimento da imagem e das narrativas encobridoras, duas dimensões: o corpo e a voz (para. 4).

A partir de ambas as contribuições, é possível considerar que o contato visual com o paciente, em situações de vídeo chamada por WhatsApp e Skype, por exemplo, não chega a ser um aspecto dificultador para que a escuta se faça, mas que, em atendimentos onde o paciente se acomode em um local com mais estímulos visuais, como cores, quadros, livros, luzes e etc., sim, pode haver uma maior dificuldade em manter a atenção equiflutuante. É preciso ter em mente que, ao contrário do setting (físico) montado e organizado pelos analistas, em consultórios ou clínicas particulares, na modalidade remota quem se ocupa de encontrar um ambiente que lhe seja agradável, sem perturbações e que mantenha a sua privacidade, é o paciente, e, a partir disso, muitas configurações podem aparecer, sem que seja possível ter qualquer controle sobre isso. 
Retornando ao, já citado, texto "Recomendações ao médico para o tratamento psicanalítico" (1912/2019), Freud (2019b) descreve que o analista deve:

\section{(...) sintonizar-se com 0 analisando, assim como o receptor} do telefone se sintoniza com o transmissor. Assim como o receptor transforma novamente em ondas sonoras as oscilações elétricas da linha, originadas por ondas sonoras, da mesma forma o inconsciente do médico é capaz de reconstituir, a partir das ramificações do inconsciente que lhe são informadas, esse inconsciente que determinou as ocorrências trazidas pelo paciente (p. 99).

Assim, é possível que o fato de estarem ambos (analista e paciente) vivendo, ao mesmo tempo, as mesmas contingências que a realidade externa impõe, como no caso de uma pandemia, tal situação pode se apresentar como um fator que contribua para uma escuta obstaculizada, ou, recorrendo às palavras do trecho supracitado: para que 0 analista não apresente as condições adequadas para o exerćício de metabolização das "oscilações elétricas"vindas do paciente. Ao contrário, o anal ista pode apresentar tendência maior a escutar o paciente a partir da sua própria experiência, de suas próprias angústias e dificuldades momentâneas. É claro que tal dificuldade não se apresenta apenas em momentos assim, podendo ocorrer em análises presenciais, à qualquer momento, no entanto, diante a um momento de excesso, que incide sobre os sujeitos de forma, objetivamente, similar, 0 analista pode ter uma maior dificuldade em diferenciar o que é seu e o que é do paciente, escutando, portanto, não de maneira equiflutuante, mas selecionando fatos que correspondam à sua própria experiência. Hornstein (1989) é pontual ao afirmar:" "o específico da escuta analítica é poder interpretar um discurso para além do narcisismo do analista, discurso que sempre deve ser escutado em sua singularidade" (p. 21).

E, éa partir da possibilidade de existência desse dificultador, que Freud (2019b) recomenda, àqueles que, porventura decidam seguir o ofício da psicanálise, que considerem que as suas próprias subjetividades e resistências são elementos participantes no processo analítico dos pacientes em tratamento e busquem, portanto, realizar a análise pessoal.

Da parte do paciente, e sobre as condiç̧oes possíveis para que ocorra, entre outros aspectos, a associação-livre, Scharff (citado por Nóbrega, 2015), aponta:

(...) o processo essencial de livre associação, a transferência, a compreensão sobre a maturação da pulsão, não precisam ficar comprometidos com o uso do telefone. A interpretação básica, o holding e a função de testemunha para o paciente podem ser sustentadas pelo analista, sem modificação (pp. 146-147).

Entende-se que a associação-livre não precisa, necessariamente, ter prejuízos em condições que sejam realizados através de atendimentos telefônicos, no entanto, ter garantido o espaço (físico) e a escuta, por parte do analista, não impedem que, alguns pacientes, acabem se valendo do "fator remoto" para que, como nos apresenta Fink (2017): "vejam a análise mais como um jeito conveniente para'desabafar' do que como um lugar para fazer um trabalho associativo dificil" (p. 328). 0 autor refere que alguns pacientes podem entender que o esforço feito para estarem presentes em uma sessão remota, é muito menor em relação àquele que demandaria deslocamento e uma série de outros investimentos, no caso de sessões presenciais. Assim, 0 investimento (psíquico) necessário para que haja a possibilidade de associação-livre se encontraria empobrecido, tornando o espaço analítico passível de se tornar um lugar meramente catártico. Naturalmente, não se trata de algo restrito ao atendimento remoto, como Fink (2017) nos alerta, "este é o mesmo tipo de problema que pode surgir na análise em que o paciente perde o seu tempo reclamando, falando de coisas do cotidiano, ou que ela nem saiba o que dizer" (p. 328), mas, em meio a um contexto de tamanho excesso, como o vivido diante a uma pandemia, essa possibilidade pode se fazer mais presente que 0 habitual.

0 autor segue e apresenta uma série de dificuldades que podem contribuir para o rompimento de uma cadeia associativa por parte do paciente, como, por exemplo: "ligaçōes telefônicas ocasionalmente ficam mudas sem qualquer aviso" (Fink, 2017, p. 330) ou conexões de internet que estejam, momentaneamente, com sinal fraco ou ausente. Somam-se a esses fatores, situações em que, por exemplo, o paciente não tenha desabilitado as notificações de seu smartphone e, ao receber mensagens, tem a sua atenção desviada para outro ponto, que não aquele ao qual estava conectado (ou conectando-se) intimamente. Há, ainda, a dificuldade que, em atendimentos por chamada de voz, pode surgir em reconhecer caso o paciente esteja chorando, sorrindo ou, enfim, expressando alguma emoção com auxilio de seu corpo. 0 analista, para Fink (2017), deve, portanto:"estar atento a tudo que seja acessível e não falhar em perguntar sobre coisas que pensa que ouviu, mas que pode ter sido, inicialmente, camuflado pela paciente" (p. 330).

É possível considerar que a ausência de contato visual em atendimentos realizados por chamada de voz, se apresente como uma dificuldade, dentre outras possíveis, para alguns pacientes que sentem a falta do "llho no olho", pois, ao contrário de atendimentos presenciais, onde o paciente ao nos fitar e, em contrapartida, ao sustentarmos esse ol har com o nosso, nos mostramos presentes e continentes, em atendimentos realizados por chamada de voz, esse aspecto desaparece, 0 que pode causar desconforto e até algum tipo de desorganização. Nesse sentido, a voz do analista não é suficiente para que haja a sustentação do paciente, falta-lhe o olhar e a presença concreta do analista, para que seja possível direcionar - a alguém - aquilo de que se fala.

Entretanto, há - também - aqueles pacientes que não apenas mantem as condições associativas analíticas, como, também podem alargá-la diante ao cenário de atendimentos remotos:

(...) certos pacientes me contaram que eles sentem que as sessões por telefone são mais íntimas do que sessões presenciais, porque eles me ouvem falando diretamente em seus ouvidos e sentem que estou mais perto pelo telefone do que quando estão deitados no divã (Fink, 2017, p. 324).

Corroborando com essa perspectiva, Aryan et al. (2015), assinalam:

(...) para alguns pacientes com dificuldade de contato, somenteà distância pode-se começar um tratamento, e, conforme 
o processo avança, progressivamente conseguem tolerar mais a proximidade. Aparentemente, esse modo permite uma maior permeabilidade das intervenções do analista, já que o paciente em sua fantasia acredita que há menos risco e que pode regular a proximidade-intimidade (p. 73).

Ou seja, não existe uma fórmula que explique, ou mesmo, se aplique, a como todos os pacientes que, eventualmente, precisem recorrer a atendimentos remotos, irão sentir-se e quais serão as implicações da modalidade não-presencial nos processos psíquicos de cada um, tal proposição seria ir na contramão do olhar singular e subjetivo que a psicanálise se propõe a lançar sobre os sujeitos. 0 que se sabe é que, como dito anteriormente, alguns pacientes não têm a indicação de atendimentos que não sejam presenciais ou, não se sentem à vontade e/ou com a mesma disposição e ligação ante ao processo e ao analista.

\section{Considerações (temporárias)}

À essa altura, soa improvável determinar considerações finais, hermeticamente fechadas, em um assunto que se encontra em constante transformação e desenvolvimento. Freud nos mostra que, o método psicanalítico, desde momentos anteriores à sua concepção, esteve permeado por um intenso processo de pensar e questionar-se, e que, em alguns momentos, erros foram cometidos, assim como acertos, mas que ambos puderam ser assimilados, aprimorados, desenvolvidos, e hoje contribuem para constituir o método que conhecemos.

É possível afirmar que, sim, o método psicanalítico pode se manter ante dificuldades extremas, como a que estamos vivenciando com o COVID-19, e que, para isso, precisa de um esforço, um incremento de libido, daqueles que se propõe a escutar e a serem escutados de forma remota. Ainda, torna-se fundamental refletir sobre as possibilidades que permeiam 0 atendimento remoto, ou seja, a sua existência, seja por meio de cartas, chamadas de voz ou de vídeo, não garante que todos, sejam analistas ou pacientes, devam sentir-se à vontade, com recursos psíquicos e/ou desejosos de sustentar uma relação nesses moldes. Dessa forma, diante a constatação de que o método psicanalítico tem condições de se manter sob a forma remota, ainda que possa enfrentar dificuldades e resistências que, talvez, em al guma outra roupagem, também apareceriam presencialmente, é importante não perder de vista as particularidades de cada situação, paciente e analista.

Diante ao inimaginável, e do que, muitas vezes, soa como catastrófico, talvez seja papel ético de um analista poder proporcionar um espaço em que possa se unir aos pacientes para, juntos, terem condições de construir a possibilidade de sobrevivência psíquica, sendo possível manter-se sonhando e imaginando, considerando estas como melhores alternativas ante às vozes exaltadas e à profusão de palavras que podem ser tanto externas quanto internas. Considerando tamanhas incertezas e a própria imprevisibilidade da situação em que vivemos, resta o não-saber, então que, humildemente, seja possível ao analista retomar, revisitar conceitos que amparem e forneçam subsídio necessário suas caminhadas. Nesse sentido, Rea (2019) é pontual ao afirmar:
(... las herramientas tecnológicas son un hecho y pueden estar también al servicio del psicoanálisis. Nos corresponde a nosotros, los psicoanalistas, el asumir la tarea creativa de transformar el espacio virtual en campo transferencial, en potencial de ligazón, en locus de construcción simbólica, de producción de pensamiento clínico. Para ello es fundamental que el sentido del psicoanálisis esté encarnado en nosotros; de ese modo podremos dar apertura a la alteridad para ser interrogados por ella, sea la del paciente 0 la de la propia tecnología. El compromiso es más costoso en los encuentros no presenciales, pero, aun así, la tarea es nuestra (para. 21).

Por fim, apesar de a atual situação, em muitos momentos, parecer (e ser) assustadora e repleta de incerteza, é preciso poder enxergar e valorizar aspectos que contribuem para que sejam mantidos o movimento e os laços que colaboram para um profícuo pensar psicanalítico, e, nesse sentido, fornecem amparo para que sigam-se ofertando espaços (ainda que remotos) para que os pacientes possam seguir transformando-se.

\section{Referências}

Alonso, S. L. (2011). A escuta psicanalítica. In S. L. Alonso (Org.), O tempo, a escuta, o feminino (pp. 105-114). São Paulo: Casa do Psicólogo.

Aryan, A., Briseño, A., Carlino, R., Estrada T., Gaitán, A., \& Manguel, L. (2015). Psicanálise à distância: Um encontro além do espaço e do tempo. Calibán: Revista Latinoamericana de Psicoanálisis, 13(2), 60-75. Recuperado de http://www.bivipsi.org/wp-content/uploads/Caliban_Vol13_ No2_2015_-port_p60-75.pdf

Belo, F. (2020). Clínica psicanalítica on-line: Breves apontamentos sobre 0 atendimento virtual. São Paulo: Zagodoni.

Fink, B. (2017). Análise por telefone, variações na situação psicanalítica. In B. Fink (Org.), Fundamentos da técnica psicanalítica: Uma abordagem lacaniana para praticantes (pp. 317-345). São Paulo: Blucher.

Freud, S. (1997). Caso 2, Sra. Emmy Von N., idade 40 anos da Livônia. In S. Freud (Org.), Casos Clínicos I (pp. 43-115). Rio de Janeiro: Imago.

Freud, S. (2010). A transitoriedade. In S. Freud (Org.), Introdução ao narcisismo: Ensaios de metapsicologia e outros textos (1914-1916) (pp. 247-252). São Paulo: Companhia das Letras. (Obra original publicada em 1916).

Freud, S. (2016). A psicoterapia da histeria. In S. Freud (Org.), Estudos sobre a histeria (1893-1895) (pp. 358-427). São Paulo: Companhia das Letras. (Obra original publicada em 1895).

Freud, S. (2019a). 0 método psicanalítico freudiano. In S. Freud (Org.), Fundamentos da clínica psicanalítica (Obras Incompletas de Sigmund Freud) (pp. 51-61). Belo Horizonte: Autêntica Editora. (Obra original publicada em 1904).

Freud, S. (2019b). Recomendações ao médico para o tratamento psicanalítico. In S. Freud (Org.), Fundamentos da clínica psicanalítica (Obras Incompletas de Sigmund Freud) (pp. 93-106). Belo Horizonte: Autêntica Editora. (Obra original publicada em 1912).

Gil, A. C. (2008). Métodos e Técnicas de Pesquisa Social. São Paulo: Atlas.

Hornstein, L. (1989). 1a aula. In L. Hornstein (Org.), Introdução à psicanálise (pp. 19-30). São Paulo: Editora Escuta.

Laplanche, J., \& Pontalis, J. B. (1992). Vocabulário de psicanálise. São Paulo: Martins Fontes. 
Nóbrega, S. B. (2015). Psicanálise on-line: finalmente saindo do armário?. Estudos de Psicanálise, (44), 145-150. Recuperado de http://pepsic.bvsalud.org/scielo.php?script=sci_arttext\&pi$d=$ S0100-34372015000200016\&lng =pt\&nrm=iso

Rea, S. (2019). El analista, Skype y lo que sucede entre ellos. Calibán: Revista Latinoamericanade Psicoanálisis, 17(1). Recuperado de https://calibanrlp. com/el-analista-skype-y-lo-que-sucede-entre-ellos/

Rivera, T. (2020, 28 de março). A tela e a outra cena ou como piscar nas sessões virtuais de análise [Blog]. Recuperado de http://psicanalisedemocracia. com.br/2020/03/a-tela-e-a-outra-cena-ou-como-piscar-nas-sessoes-virtuais-de-analise-tania-rivera/?fbclid=IwARoWkx5A7uj0y9u5_ YD9JPFgk1asQAEQvBhilL2TyrZEIR5tQ4Kk5M-LLbnY. 